attend activities of motor elements; but I find that these very cases are claimed by those who repudiate the " out-going current doctrine." I suppose the alterations in size of an after-image during changes of accommodation will be similarly claimed. The following, which I used to think a very strong thing favouring the doctrine that mental states attend activities of motor elements in the highest centres - the alteration in shape of after imageswill, I suppose, be claimed too. If we obtain an after-image of a square, and then project it on to an inclined sheet of paper, the spectral square becones oblong. There is here a change in muscular activity, but it may be said that no mental states attend activities of the motor nervous arrangements effecting it, but only of the sensory elements in activity from changes in the muscles put in action. Let us take an extreme case. A man has progressive muscular atrophy to the degree that he has no muscles in the right arm, and no anterior horns for them. Yet he localises a touch, and for the sake of argument I will grant that he does so as well as ever. I suppose the localisation implies movement, in this case the so-called "ideas of movement." It is true that the patient has no muscles, but the whole of his sensory nervous system is intact, and the whole of his motor nervous system with the exception stated. My submission is that the patient localises the impression becanse, besides sensory activities, there are also activities of his highest motor centres.

\title{
Professor HorsLey.
}

As some cases I have published have been introduced into this discussion, I shall be very glad of the opportunity to say something with respect to the representation of the " muscular sense" in the so-called motor region of the cortex. In the first place, let me say that if I use the terms usually employed, apparently with a twofold meanirg, I hope I shall not be misunderstood. Thus if I speak of "sensation" I do not mean by that term, in every sense that I may use it, to connote consciousness. We are very much in want of a term to express better what is generally understood by the word sensation. The changes which go on in nerve endings when they are irritated require some other expression than our common word sensation, which conveys the meaning of the conscious perception of the process which is going on peripherally. If therefore I use the word "sensation," I hope to be understood that in a large majority of cases $I$ shall be referriug to a conscious perception of the changes in the nerve endings, but I may also mean the changes which go on in the nerve endings 
without the accompanying conscionsness. Further, a great deal of stress has been laid on the use of the word motor. What Dr. Ferrier calls "motor," Dr. Bastian, for equally good reasons, calls "efferent"; what Dr. Bastian calls "efferent," Prof. Schiff calls "kinesodic." Now it seems to me that of these the term efferent is the more general in meaning, therefore I shall, as far as possible, avoid speaking of " motor," and I shall apply the term áffurent to the impulses which originate the so-called motor sense. There is no doubt as to what is meant by the word afferent. It seems to me that so much stress has been laid upon the meaning of these terms as to introduce no little confusion into this matter. Well, with respect to the first point, viz., the cases of my operations which apparently throw light on this question, personally I desire to lay no great weight on these cases. There are not enough of them yet for us to speak absolutely from the evidence they afford. There is among them one case of cerebral tumour, in which I did, as Dr. Ferrier rays, make an incision deeply down into the corona radiata. To my mind the knife did not pass down deeper than one inch. Personally I do not consider that that incision injured the fibres going to the so-called sensory tracts of the cortex, but until the patient dies, I would not like to say exactly what was the extent of that lesion, and therefore, as I stated in the description I gave of my cases in the 'British Medical Journal' for Oct. 10,1886 , I would not rely on their evidence further than to rogard them as tending to show that the so-called motor region is the centre of muscular sense. I would put aside that case which Dr. Ferrier has quoted of the man Henderson, for although there certainly seemed to be a delay on the onset of the anæsthesia after the operation, the whole surroundings of the case are so very complicated that even after the death of the patient I should not like to adduce it alone in support of an argument one way or the other. When one has a series of something like twenty-five or fifty cased, then I should like to come forward with some more positive statements. These cases however, to my mind, do tend to show there is possibly some representation of the so-called motor sense in the motor cortex. Lastly, we come to the question of the theoretical possibility, that the muscular sense is represented in the so-called motor cortex. It is not for me to enter to-night into questions of much deeper inport, questions of philosuphic thought. It would be presumptuous on my part, after what has been said before, by Drs. Bastian, Ferrier, Ross, and Sir J. Crichton-Browne ; bnt as regards the anatomy, i.e. the mechanism of the function of which we are now discussing, I should like to say a few words. Dr. Ross has referred to the two main histological divisions of the 
cortex, viz. the large ganglionic, the so-called motor cells of the fourth layer, and the smaller cells which exist in vast numbers in the rest of the grey cortex, and he believes that consciousness is correlated with the functions of the smaller cells, and not with the larger ones. I would venture to say that such a belief as that is of course a personal matter, but argument of analogy seems to me to be strongly in favour of this contention. But there is another mode of regarding the anatomical facts just mentioned, and that is the possibility of each being correlated to efferent and afferent functions respectively. Of course, theoretically, we may for many reasons regard the few large corpuscles as essentially efferent, and the small cells as essentially afferent in function. For myself, I am quite prepared to hear it proved some years later that the smaller cells bave a distinctly sensory aspect, and that the larger cells have a distinctly motor aspect. Until this anucomical problem has been cleared up, we must leave the question entirely open whether the smaller cells are kinæsthetic or not. Dr. Ferrier would say absolutely that they are not; that there is no representation of sensation in this "motor" region, and that therefore the function of these smaller cells is motor. That the whole sectior of the brain cortex in this region is motor, it is very difficult to believe, though such a view is apparently supported by snme very considerable facts. Finally, as regards experimental evidence, enough has been said on that point to avoid adding to it. The only experiments that will show anything are the observations on human beings. Until after small localised portions of that region have been excised, and a reliably large number of such cases have been thoroughly examined and reported, it will be impossible to do more on this problem than admit. its present insolubility.

\section{Professor HaYcraft.}

I should like to draw attention to a change which has recently taken place in the views of many physiologists respecting the functions of nerve cells and nerve centres. This change is due, I think, to a more philosophical conception of the development of the brain, and to the introduction of improved technical methods for its histological investigation. I venture to make these remark8, because in my opinion the discussion, as to whether certain regions of the cerebral cortex are motor or sensory; can resolve itself into a statement of what they really are in terms of these newer conceptions. We must remember that the central nervous system in higher animals is interposed between the sensory surfaces of the body and the muscular system, etc. and that the nerrous connec- 